\title{
Vocational Students' Ways of Handling the Academic/Vocational Divide
}

\author{
Lisa Ferm* \\ Linköping University, SE-581 83 Linköping, Sweden \\ Received: 15 May 2020, Accepted: 16 October 2020
}

\begin{abstract}
Purpose: The focus of this article is on Swedish vocational students' own thoughts about different types of knowledge and how these thoughts relate to the forming of their vocational identities. The article reports on a study which investigates how vocational students handle the division between theoretical and practical knowledge as they learn to become skilled industrial workers. Theoretical and practical knowledge are often presented as dichotomies in a hierarchy, where theoretical knowledge is more highly valued than practical knowledge. The division between theoretical and practical knowledge is known in research as "the academic/vocational divide". This divide is particularly relevant to vocational students, as they need to deal with both types of knowledge as they navigate between the contexts of school and work.
\end{abstract}

Methods: This study is part of a research project on vocational students' learning and identity formation. The empirical material is based on qualitative interviews with 44 students enrolled on the industrial programme at Swedish upper secondary schools.

Findings: The study revealed three different ways in which vocational students handled the academic/vocational divide: Placing higher value on practical knowledge than on theoretical knowledge, reinforcing the separation between school and work, and selecting theoretical subjects as useful tools for the future.

${ }^{\star}$ Corresponding author: lisa.ferm@liu.se

ISSN: $2197-8646$

http://www.ijrvet.net 
Conclusions: Two conclusions drawn from the study are that students are aware of the status differences and divisions between practical and theoretical knowledge, and that they handle the academic/vocational divide in an active manner. Students make choices that will help them form a vocational identity or that will give them opportunities for further education and alternative careers. This article challenges and contradicts the image of vocational students as unmotivated and unintellectual, instead portraying them as knowledgeable actors who make strategic choices for their future and are active in forming vocational identities within vocations that require deep and advanced knowledge.

Keywords: Vocational Identity, Industrial Programme, Academic/Vocational Divide, VET, Vocational Education and Training

\section{Introduction}

All modern societies are influenced by an academic/vocational divide in some way (Young, 1993). At a societal level, the academic/vocational divide relates to aspects such as class and gender, and reveals a lot about hierarchies and status related to different kinds of knowledge and work (Niemi \& Rosvall, 2013; Rose, 2008). Vocational education has been accused of reproducing class by preparing working-class students for a working-class future (Arum \& Shavit, 1995). When it comes to gender, working class masculinities are generally viewed as being incompatible with theoretical knowledge (Niemi \& Rosvall, 2013). Theoretical knowledge has a higher status within the world of education, while practical knowledge enjoys a higher status within the world of work. Vocational education is circumscribed by both these partly competing sources of status (Billett, 2014).

Additional contradictions have been ascribed to the historical tension between the "outsider perspective" on vocational education, e.g. among power elites in society with a distant view of practical knowledge, and the "insider perspective", i.e. those actors that are engaged in skilled work and vocational education (Billett, 2014). In this article, the focus is on the "insider perspective", i.e. the student perspective, including how various kinds of knowledge are valued, transformed and recontextualised by students as they alternate between workplaces and school (Evans et al., 2011). When students are at school, they are subject to the academic/vocational divide as an institutionalised part of the education system. This divide is manifested in the physical contexts of schools, where vocational education and academic education are often located in different buildings or parts of the school (Nylund et al., 2018). Even within vocational education, the academic/vocational divide is present through a clear separation of vocational and general subjects (Nylund et al., 2018). This separation, together with the different logics that schools and workplaces operate with, present a challenge for 
students who are expected to integrate knowledge learned at school with knowledge from the workplace (Baartman et al., 2018).

This study is informed by timely research demonstrating how vocational students integrate knowledge between school and workplaces (Berner, 2010; Gustavsson \& Persson Thunqvist, 2018; Persson Thunqvist \& Axelsson, 2011) when learning their vocations. Different types of knowledge become relevant for vocational students (Rose, 2008) as they navigate between the contexts of school and workplaces. Students need to make sense of and recontextualise (Evans et al., 2011) the meaning and relevance of theoretical and practical knowledge in the field of tension between the world of school and the world of work. However, there is little research on how vocational students learning to become industrial workers use and change knowledge between school and work. Therefore, this study aims to investigate how vocational students handle the division between theoretical and practical knowledge as they learn to become skilled industrial workers.

Forty-four vocational students on the industrial programme at Swedish upper secondary schools were interviewed about theoretical and practical knowledge, how they learn vocational skills and the industrial vocation. Vocational education refers to Swedish upper secondary programmes that prepare students for working in specific vocations, while academic education refers to preparatory programmes for higher education or post-secondary academic education. In Swedish vocational education, theoretical knowledge comprises both general theoretical subjects and theoretical vocational subjects. In this paper, both types of theoretical subjects are referred to as "theoretical knowledge". In contrast to theoretical knowledge, practical knowledge here refers to knowledge practised in the schools' workshops, or during workplace-based learning at companies.

The paper continues by outlining the theoretical framework, which includes the concept of recontextualisation for analysing students' learning and use of knowledge in and between school and workplace contexts. Thereafter, previous research on the academic/vocational divide and its implications for vocational students' vocational learning is presented. The theoretical section is followed by a presentation of the Swedish upper secondary school system for vocational education, with a particular focus on the industrial programme. The method section describes the data collection and analysis. Thereafter, the findings are presented in three different themes that reveal students' ways of handling the divide between theoretical and practical knowledge. Finally, the findings are discussed, and the paper ends with conclusions and some practical implications of the study. 


\section{Theoretical Framework}

In this section, the concept of recontextualisation is presented. The concept of recontextualisation was selected to provide a way of analysing the students' learning and knowledge use in and between school and workplace contexts. Thereafter, research on the academic/vocational divide and its impact for vocational students is described.

\subsection{The Concept of Recontextualisation}

The concept of recontextualisation describes the process of using knowledge gained from one context in another context (Evans et al., 2011). When various types of knowledge move between different contexts, for example the contexts of school and workplaces, it is not simply a matter of transfer, but rather a process of changing knowledge, context and people (Evans et al., 2010). What constitutes a context is broadly interpreted by Evans et al. (2011) and includes schools of thought as well as geographic places. Norms and traditions of different communities can also be understood as contexts (Evans et al., 2011). Both theoretical and practical knowledge are, from the perspective of recontextualisation, viewed as contextualised (Evans et al., 2011). Hence, Evans et al. (2011) challenge the view that theoretical knowledge, unlike practical knowledge, lacks links to specific contexts, which is a view that has contributed to the low status of practical knowledge and has further widened the theory-practice gap.

Furthermore, this perspective highlights the potential of the workplace as a locus for knowledge production and learning (Evans et al., 2011). Thus, recontextualisation is a way to handle the academic/vocational divide that shows the equal value of both theoretical and practical knowledge (Evans et al., 2011). In addition, it is impossible in reality to distinguish between theoretical and practical knowledge, as work often requires theoretical knowledge which cannot be separated from practical knowledge (Niemi \& Rosvall, 2013).

Knowledge gained at school needs to be changed and integrated with other types of knowledge in workplaces to become useful to students (Evans et al., 2011). However, the type of knowledge that is valued at school differs from the type of knowledge that is prioritised at workplaces (Gustavsson \& Persson Thunqvist, 2018). Gustavsson and Persson Thunqvist (2018) found that school provides vocational students with knowledge that may facilitate their workplace-based learning, where the students' skills are further developed as they participate in daily work with more experienced co-workers. The students' participation in daily work with other workers is also important for the development of vocational identities, as they are mediated by the norms, ideals and values from both work and school. Identifying bridges between these contexts is therefore important for vocational students who move between school and the workplace (Evans et al., 2011). 
During workplace-based learning, students put both theoretical and practical knowledge to use while learning their intended vocation, which is an important part of their vocational identity formation (Gustavsson \& Persson Thunqvist, 2018). Hence, the recontextualising of knowledge can be viewed as a process that is closely connected to vocational identity formation (Evans et al., 2011). Vocational identity is here understood as a desire to live up to the norms and ideals of a vocation (Armishaw, 2007), while being able to express motivation for entering that specific vocation (Evans et al., 2010).

\subsection{The Academic/Vocational Divide in Vocational Education}

Within previous research on vocational education, two different but interconnected strands of research are particularly relevant for this study: Research on the boundary between theoretical and practical knowledge, and research on the low status of vocational education relative to academic education and how to overcome the difference in status.

Firstly, concerning the boundary between theoretical and practical knowledge, Schaap et al. (2012) suggest that vocational education is governed by two different rationalities; on one hand the rationality of school, and on the other hand the rationality of workplace-based learning. The rationality of school is associated with theoretical knowledge, while practical knowledge is connected to the rationality of workplace-based learning. Vocational students need to integrate their experiences from the workplace with what they learn at school and vice versa (Baartman et al., 2018) in order to form a vocational identity (Gustavsson \& Persson Thunqvist, 2018). As Aarkrog (2005) points out, both theoretical and practical knowledge are crucial for developing vocational competence, even though they are often being portrayed as conflicting perspectives.

Secondly, regarding the status of vocational education in comparison with academic education, Chankseliani et al. (2016) illustrate how a combination of theoretical and practical knowledge is often suggested as a way to address the status differences between academic and vocational education. However, efforts to overcome these status differences by integrating different types of knowledge still tend to place a greater value on theoretical knowledge by expecting it to strengthen and complement practical knowledge, and never the other way around (Hyland, 2002; Rose, 2008). An alternative way to overcome this status hierarchy is to stop comparing different types of education and knowledge, and to focus instead on the value of vocational education in itself by reinforcing vocational skills and expertise (Chankseliani et al., 2016). In addition, Hyland (2002) suggests that, in order to overcome these status differences between theoretical and practical knowledge, it is crucial to show the learning potentials of vocational education that contains deep, advanced and continuous learning, rather than merely focusing on pinpointing similarities between vocational and academic education. 


\subsection{The Academic/Vocational Divide - Implications for Vocational Identities and Learning}

Research on vocational education has demonstrated how the academic/vocational divide has important implications for vocational students' identities and thus their learning. It has shown how vocational students are positioned in at least two different social identities. On the one hand, in the dominant historical and educational discourse about the academic/ vocational divide (see e.g. Billett, 2014), vocational students are positioned as non-academics, lacking the intellectual capacity for theoretical work. On the other hand, vocational students are positioned as (becoming) skilled workers, following advanced and demanding vocations that require deep knowledge. Hence, while the former social categorisation implicates a negative identification, associated with the formation of marginalised school identities, the latter connotes a process of identification with future-oriented vocational identities; it challenges one-dimensional conceptions of the academic/vocational divide in the context of modernised forms of vocational education targeting skilled vocations (see Billett, 2014).

The image of vocational students as non-academic learners has been shown to be shared by both vocational students themselves and their teachers (Brockmann \& Laurie, 2016; Rosvall et al., 2017). In the classroom, the image of vocational students as being unmotivated for theoretical general knowledge results in low expectations from teachers, which subsequently leads to passive, low achieving students (Rosvall et al., 2017). Vocational education is often viewed as an option for students who are uninterested in and incapable of acquiring academic knowledge (Nylund et al., 2017), while academic education is recommended to students with higher grades (Tønder \& Aspøy, 2017). In addition, low achievers from comprehensive school are often guided towards vocational education, rather than academic education (Rosvall et al., 2017). The students' interpretations of their own capabilities leave them feeling less intelligent than their peers who are studying more academic educations (see Rose, 2008). Atkins and Flint (2015) found that vocational students themselves say that they are considered to be stupid for choosing the vocational track over the academic. A common criticism of vocational education is that it only provides short-term and context-dependent knowledge (Beicht \& Walden, 2015).

Another strand of research challenges this notion that vocational students are unmotivated low achievers in the classroom, and instead focuses on the deep and complex knowledge they possess as skilled workers (e.g. Billett, 2014; Rose, 2008). In line with this, a recent study shows that deep and advanced vocational knowledge is important for shaping vocational students' learning trajectories towards vocations in the industrial sector (Ferm et al., 2019).

This view of vocational students possessing advanced knowledge through work is a view that contrasts with images of vocational students as unmotivated and unintelligent, and instead demonstrates the complicated processes of problem solving (Rose, 2008) and the high level of conceptual knowledge (Billett, 2014) that vocational knowledge comprises. In 
line with this perspective, the vocational students themselves tend to place high value on their education, even though they are aware of the low status ascribed to it in comparison with academic programmes (Atkins \& Flint, 2015). In addition, they often express a sense of contempt towards more academic forms of education and knowledge (Rose, 2008).

However, previous research has indicated that the learning that takes place at school can be a valuable knowledge base for vocational students as they enter the workplace (Kilbrink et al., 2014; Rintala \& Nokelainen, 2019) and can also function as a springboard to a vocation (Gustavsson \& Persson Thunqvist, 2018). In addition, Swedish vocational education requires for pass grades in several theoretical subjects in order for students to receive a vocational qualification. Slaats et al. (1999) found that students' own motivation to study vocational education is often related to general goals concerning their future vocation, and their vocational qualification is viewed as a way to reach that goal.

Furthermore, vocational students tend to perceive theoretical courses or knowledge as useful when it is directly applicable to their work (Schaap et al., 2012). Both vocational students and their teachers want to see more integration between theory and practice. However, the curriculum and examination forms are presented as a challenge to this (de Bruijn \& Leeman, 2011), and the workplace offers limited opportunities to show students the connections between theory and practice due to the requirements for effective production (Kilbrink et al., 2018). Hence, vocational students often experience weak links between theory and practice (Rintala \& Nokelainen, 2019). Presenting vocational education as an entity requires close cooperation between the school and the workplace (FitzSimons \& Boistrup, 2017), and it is argued that students need to see their education as a whole in order to understand the value of theoretical knowledge (Kilbrink et al., 2014). This study focuses on how vocational students handle the division between theoretical and practical knowledge as they learn to become skilled industrial workers in the contexts of both school and work, which has rarely been examined in earlier research.

\section{Research Context}

The Swedish upper secondary school system consists of 18 programmes: Six higher education preparatory programmes and twelve vocational programmes. In the vocational programmes, the tension between theoretical and practical knowledge is visible in the way vocational education policies have alternated between prioritising general and workplace-related knowledge (Persson Thunqvist et al., 2019). The two most recent reforms in Swedish upper secondary education have switched between prioritising general theoretical knowledge and workplace-based learning. The 1994 reform aimed to increase vocational students' general knowledge by expanding vocational education and providing the students who completed it with general eligibility for higher education (Virolainen \& Persson Thunqvist, 2017). 
In the 2011 reform, the pendulum swung in the other direction as the goal was to leave students better prepared for the labour market by increasing workplace-based learning (Persson Thunqvist et al., 2019). The 2011 reform is often portrayed as prioritising market value and the needs of the labour market (Nylund et al., 2017). The stronger focus on workplacebased learning than on general theoretical knowledge in vocational education was motivated as an attempt to prevent unemployment and problems with young people dropping out of upper secondary school (Andersson et al., 2015). However, the decreasing general theoretical knowledge in vocational education is also suggested to lead to fewer opportunities for lifelong learning than academic education (Lavrijsen \& Nicaise, 2017).

The vocational education examined in this article is the industrial programme, one of the 12 vocational upper secondary programmes. As with all Swedish upper secondary education, the industrial programme lasts for three years. The industrial programme has four different directions, all of which prepare students for different vocations in the industrial sector. Potential vocations after the programme include welder, machine operator, process operator and operating technician. As with all other Swedish upper secondary vocational education, the industrial programme includes a set of mandatory general theoretical subjects such as mathematics, English, Swedish, history and religion. In addition, it also gives students the option to study the additional courses in mathematics, Swedish and English that are required for general eligibility for higher education. All vocational education also includes several vocational subjects. On the industrial programme, these include chemical and mechanical production processes, production development and welding.

Like all other Swedish upper secondary vocational programmes, the industrial programme is offered as two different models: either as school-based vocational education or in the form of an upper secondary apprenticeship. Both models share the same subjects and learning goals; they differ only in respect of the amount of time spent on workplace-based learning. The school-based model must include at least 15 weeks of workplace-based learning, while no less than half of the entire education time in the apprenticeship model should comprise workplace-based learning. The role of the workplace is twofold during the workplacebased learning: It continues to be a place for production, while also functioning as a learning environment for vocational students. Students are entitled to supervisors during their workplace-based learning, and they are there under the supervision of their schools.

\section{Method}

This study of vocational students' ways of handling the academic/vocational divide, is a part of a larger research project focusing on industrial students' learning and identity formation during their workplace-based learning. 
This sub-study was conducted by the author. A qualitative research methodology was employed. Data was gathered by conducting semi-structured interviews with 44 students enrolled in the industrial programme at Swedish upper secondary schools. ${ }^{1}$

\subsection{Selection of Participants}

To gain access to the students, the principals responsible for the industrial programmes were contacted with information about the research study. The principals then communicated with the students enrolled on the schools' industrial programmes and the selected students participated in the interviews voluntarily. An important criterion for the selection of students was that they had experiences of workplace-based learning within the industrial sector. The participating students were between 18 and 20 years old. Thirty-three were boys and 11 were girls. The sample has a relatively high percentage of female students in relation to students commonly enrolled on the industrial programme. Eight students were in the second year of the programme, while the remaining 36 were in their third and final year. Students from both the school-based model and the apprenticeship model were interviewed. The students came from six different schools which collaborated with local small, medium-sized and large industrial companies located near the schools.

\subsection{Data Collection}

The interviews were conducted by the author and two other researchers who were involved in the overall research project. The three researchers all had experience of conducting qualitative interviews. The interviews with the students took place at the schools and lasted for about one hour each. To ensure coherence between the researchers, a semi-structured interview guide was used and the first interviews were carried out in pairs of researchers to calibrate the questions asked and their follow-up in the interview situation. The interview guide contained questions about different ways of learning industrial work, as well as the value and meaning of theoretical knowledge and practical knowledge. All interviews were transcribed verbatim.

\subsection{Data Analysis}

Each interview transcript was repeatedly read in order to gain familiarisation with the material. The next step entailed identification of expressions of the students' views of theoretical knowledge - both general subjects (such as mathematics and English) and theoretical voca-

1 This sub-study is part of the abovementioned research project, which has been approved by the Regional ethics board in Linköping (ref. 2014/438-31). 
tional subjects (such as welding). All the individual pieces of information about the students' views of the theoretical courses were collected in one document and were thereafter analysed in relation to one another. The students often compared theoretical knowledge to practical knowledge, and the context of school with the context of workplace-based learning. In the new document, the material was sorted into the following categories:

1. The students' views of the relevance or irrelevance of theoretical and practical knowledge.

2. The students' views of the relevance or irrelevance of aspects of theoretical knowledge.

3. The students' views of their own and other industrial students' conditions for learning theoretical and practical knowledge.

4. The reasons the students gave for choosing, or not choosing, to study the optional theoretical courses that lead to eligibility for higher education.

5. The connection (or lack of connection) that the students found between theoretical and practical knowledge.

In a second round of analysis, the empirical material under categories 1-5 was compared. During this phase of analysis, three themes emerged showing how students handle the academic/vocational divide. These themes are placing higher value on practical knowledge than on theoretical knowledge, reinforcing the separation between school and workplaces, and selecting theoretical subjects as tools for the future.

\section{$5 \quad$ Findings}

The findings are presented in the form of the three different themes, each representing a way in which vocational students on the industrial programme handled the academic/vocational divide by using theoretical and practical knowledge.

\subsection{Placing Higher Value on Practical Knowledge Than on Theoretical Knowledge}

One way in which the students handled the academic/vocational divide was to place higher value on practical than on theoretical knowledge. The students described themselves as practically oriented people who prefered workplace-based learning to classroom learning at school. 
I think it's much more fun to be out on workplace-based learning than being in school. I learn a lot more because I know what everything I do is used for.

Studying theoretical knowledge at school, such as reading course literature and carrying out various written tasks, could even be viewed as a hindrance to the students' acquisition of practical skills at workplaces.

I like to do things practically. It's a bit like it doesn't exist if it's on paper, but if I have it in front of me it's easier to understand.

The industrial students sometimes handled the divide by arguing that it was possible to manage the vocational workplace activities without any theoretical knowledge but not without practical knowledge; therefore, the practical knowledge was more highly valued. The valuing and mastering of practical knowledge may be interpreted as a crucial aspect of forming a vocational identity as a skilled industrial worker. In the students' ways of arguing for the higher value of practical knowledge compared to theoretical knowledge, they also handled the divide by emphasising that it was more important to know how to do the work than to understand the theory behind it.

You can manage to weld without knowing the theory, but if you only know the theory and are not able to weld well, you can't exactly work with it.

The students' valuing of practical knowledge was also expressed in what they said about further education. Further studies were viewed as a second choice if they were to face an uncertain labour market and unemployment, or if they wanted to change career path.

If I change my mind or if I can't get a job, I will still have something to do while I'm unemployed - I can go to school.

The industrial programmes' courses that gave general eligibility for higher education often created a conflict of interest for the students. In order to have the opportunity to participate in these courses, they often needed to take time away from their scheduled workplace-based learning. This choice presented a dilemma between the students' ambitions to prove their engagement at industrial workplaces and preparing themselves for alternative future options. Faced with this dilemma, the majority of the students chose the workplace-based learning rather than studying the courses that provided general eligibility. Therefore, they postponed alternative plans to continue to higher education, instead prioritising the vocational route that strengthened their vocational identity. As the students placed higher value on practical knowledge than on theoretical knowledge, they also expressed identification and loyalty with the workplace. 


\subsection{Reinforcing the Separation Between School and Workplaces}

The students talked about school and the workplace as two completely different contexts. According to the students, the workplace valued concrete practical knowledge rather than abstract, general theoretical knowledge which was associated with school.

R: What was it like getting used to it in the beginning, how to behave in the workplace and things like that?

S: Well, in the beginning I thought it was a bit strange, almost a little nervous. Now it's no problem, it feels natural.

R: Can you give an example of that?

S: Well, it was a long time ago, I just know that I felt different, very different.

R: Different from school?

S: Yes? ... I only know that it was completely different from school.

The separation between school and the workplace was also evident in what the students said about the differences between vocational and higher education preparatory programmes; the programmes were located in different buildings or on different sides of the school. The students also separated activities performed at school and those performed at workplaces, which were perceived as "doing something for real". The students' alignment with the ideals of the workplace can be seen as a sign of their identification with the world of work rather than the world of school. The student quoted below compares a school with a strong focus on workplace-based learning to a school with more theoretical knowledge, and argues that the former is a better environment for learning the vocation.

Well if you look at for example (name of another school), they sit behind a school bench and read about welding for the whole of the first grade, and then they have a workshop where they can do some welding. And then they maybe do workplace-based learning for two weeks, then they're back at school for two weeks, and they continue like that. What kind of insight do they get into real working life? Well I think that we get more of the practical knowledge, but their welding technique and everything that they have read about may be better. But I think you gain more from being out (at workplace-based learning) from the beginning and seeing 'this is what it's like'.

The students' separation of school and work created distance between the students on the industrial programme, whom they identified as workers, and the students on higher education preparatory programmes, whom they viewed as theoretical learners. The students associated studying theoretical knowledge with the school context, and they sometimes viewed it as the opposite of working and living a real life. 
To just sit and write and study things that are totally unnecessary to know. I'm so sick of it, I just want to get rid of it, get out there and make money instead, finally start living.

The students viewed practical knowledge as being connected to their reality, while theoretical knowledge was generally defined as studying unnecessary subjects. Furthermore, the students rarely described the integration between theoretical subjects and practical knowledge. However, when the value of theoretical knowledge was mentioned in the interviews, it mostly concerned the subjects of mathematics and English.

\subsection{Selecting Theoretical Subjects as Tools for the Future}

The students selected and made use of theoretical knowledge that supported their workplace-based learning. This meant that they handled the academic/vocational divide by attributing meaning not only to practical knowledge, but also to theoretical knowledge that they thought was useful for mastering a vocation and forming a vocational identity. The students spoke about theoretical knowledge as being useful in (at least) two different ways. The first involved using theoretical knowledge as a tool to achieve their chosen industrial vocation, while the second involved using theoretical knowledge as a tool for further studies.

The first way that students found theoretical knowledge to be useful was to gain access to a vocational future within industry. The students described mathematics, Swedish and English as important subjects to obtain a vocational qualification, and hence crucial for their vocation as industrial workers.

Our vocational qualification here, well it means a lot, to have a pass grade in maths, Swedish, English and... we have another course that's called 'Man and industry', which we are studying now. I think they all automatically become really important to manage.

The students described mathematics as being useful in order to calculate measurements and geometries in the workplace. One student reflected on how some of the older workers struggled in the workplace because they lacked mathematical knowledge.

Some older workers there (at the workplace-based learning) haven't had the same education in maths that we get today. And they're always standing with a calculator, scratching their heads...

Language skills in English (and sometimes in Swedish) were also required in the workplace to be able to read product descriptions and other work instructions during workplace-based learning.

I can imagine that English skills are good to have because a lot of tools have English descriptions on them and, well, if you want to be a travelling assembler, English can be useful. 
The students also described knowledge of English as useful when meeting foreign customers and business partners. Theoretical subjects other than English, mathematics and theoretical vocational subjects were sometimes also stressed as being relevant for learning the vocation as skilled industrial workers. For example, students said that in history and civics, knowledge about history and politics connected to industrial work were meaningful in order to gain a contextual understanding of the industry and industrial development.

Theoretical vocational subjects learned at school were important in the sense that they were used by the students to appear knowledgeable in the workplace and not look stupid in front of their colleagues.

About half of what I've learned at school is from the workplace-based learning, from doing it for real, not just on paper. But the knowledge I gained at school before entering the workplace has also played a significant role.

The second way that students spoke about theoretical knowledge as being useful was as a tool for proceeding to higher education. Some students saw that theoretical knowledge was like a bridge to higher education or an alternative future career.

S: I have chosen to study extra subjects because it opens up possibilities for quite a lot of things, if you want to continue studying, for example I could become a nurse, a speech therapist or something like that.

R: But working as a nurse or a speech therapist, that's quite different from industrial work?

S: Yes, it's very different, but I felt it could be something that I could maybe become when I'm older or really tired of industrial work all of a sudden, then I still have other options.

The students who chose to study extra courses for general eligibility to higher education wanted to keep the door open for a possible future career change.

I want to become a firefighter, so I need to study Swedish and civics 2, I think. Some students in my class have chosen courses in maths, Swedish and English. If they were to study more later, which I don't think they will, but if they want to, they wouldn't have to go to municipal adult education and take more courses.

Hence, theoretical knowledge could be used both to live up to the requirements of an industrial vocation and to deal with an uncertain future. 


\section{Discussion}

The findings of this study show that the students handled the academic/vocational divide in three different ways: by placing a higher value on practical rather than theoretical knowledge; by reinforcing the difference between practical and theoretical knowledge; and by defining some subjects such as mathematics and English as useful for their future, and other subjects as completely irrelevant knowledge. Firstly, by placing a higher value on practical knowledge than on theoretical knowledge, the students turned the status hierarchy upside down (see also Atkins \& Flint, 2015). The students thereby changed the meaning of the academic/vocational divide; this implies that the meaning of theoretical knowledge gained in the school context was interpreted as being less valuable than the workplace-based learning. The students highlighted the advanced, deep knowledge involved in their workplace-based learning rather than focusing on finding similarities with preparatory programmes for further education in order to overcome the status hierarchy (see Hyland, 2002). In addition, the vocational students tended to devalue the type of knowledge offered on preparatory programmes for higher education (see Rose, 2008). Here, the recontextualisation was manifested as a sensemaking process in which the vocational students valued practical knowledge, and in which they shifted the norms and traditions of school towards the norms and traditions of the world of work. Society's general view of practical knowledge as being less valued (e.g. Billett, 2014) was challenged and opposed by the students, who instead ascribed a higher status to this type of knowledge in the context of vocational education.

Secondly, the students both acknowledged and reinforced a separation between school and work that was already institutionalised within society in general as well as within the education system (Schaap et al., 2012). This separation was reinforced by the way that the students talked about the completely different knowledge valued at the school and in the workplace. They also spoke about how academic and vocational education was separated into different buildings (Nylund et al., 2018) and into activities carried out at school or in the workplace. In their separation of school and work, the students emphasised the workplacebased learning and practical knowledge as being connected to the real world and real life, in a way that school and theoretical knowledge were not. The contexts of school and the workplace implied more than just geographical settings; they were also interpreted as different sets of norms and traditions (Evans et al., 2011). Hence, the education was not perceived as an entity, which may prevent students from appreciating the value and utility of theoretical knowledge (Kilbrink et al., 2014).

The students actively formed vocational identities by aligning with the norms and traditions of the workplace rather than those of school, and they viewed the logics of school and work as completely different to each other (Schaap et al., 2012). This can be interpreted as a rational response to the institutional settings of vocational education, where theoretical and practical knowledge are separated and the goal is to prepare students for a future within a 
specific vocation. Furthermore, in the context of vocational education, the students reinforced the differences between theoretical and practical knowledge to such a degree that the knowledge types seemed to completely lack connections to one another. Aligning with the norms and ideals of industrial workplaces, the vocational students recontextualised theoretical knowledge as being completely separate from the world of work. The students' alignment with the world of work and how workplaces valued theoretical and practical knowledge can be interpreted as crucial elements of their vocational identification formation as industrial workers. This separation can also be interpreted as a response to the tensions and lack of integration between practical and theoretical knowledge presented by their education, even though vocational competence actually requires both types of knowledge (Aarkrog, 2005).

Thirdly, it is interesting to note the somewhat contradictory fact that students not only reinforced the separation of practical and theoretical knowledge, but also bridged the divide between theory and practice by selecting theoretical knowledge that they viewed as being useful for their vocational future. This was a way of integrating the context of school with the context of the work, which also seemed to be relevant for the students' learning trajectories in relation to their vocational identity formation within the industrial sector (Ferm et al., 2019).

The theoretical knowledge from the context of school that the students deemed to be particularly useful was courses in mathematics and English, which could be used in the workplace. The students put knowledge from school to use during their workplace-based learning, and some theoretical subjects were more useful for achieving a desired future. As Aarkrog (2005) notes, both practical and theoretical knowledge are crucial for learning a vocation. However, regardless of how much the school focused on the usefulness of theoretical knowledge in industrial workplaces, the students themselves selected the types of knowledge that were useful for doing the job together with more experienced workers at workplaces. Real-life workplace situations invoked theoretical knowledge, activated it and changed it so it could be integrated with the current workplace context (see Evans et al., 2011). This could be the case when students read instructions in English in the workplace, or when they had to calculate measurements in their work.

To conclude, the students' ways of handling the academic/vocational divide were thus connected to their learning trajectories (Ferm et al., 2019) in the form of future plans and careers. Within industrial vocations, certain theoretical knowledge such as mathematics and English were required in order to be able to handle the daily work, while other types of theoretical knowledge could instead be used to gain eligibility for further education in the future. Hence, the students related to vocational identities in different ways as they put theoretical knowledge to use in their skilled industrial work or used knowledge to keep the door open for alternative vocational identities in the future.

Regarding their future transitions to employment after completing the industrial programme, the students often stressed the importance of a vocational qualification. To obtain 
this qualification, it was necessary to get a pass grade in several theoretical courses on the industrial programme. The students often described this qualification as a crucial goal in order to get an industrial job or change their career path, which motivated them to do what was required to achieve it (see also Slaats et al., 1999). However, the students were rarely motivated to do anything beyond the general requirements, as it was the vocational qualification that mattered and not the grade. This is a logical way of reasoning, as vocational students have the opportunity to study the courses needed for general eligibility for higher education, either during the vocational programme or later, through further education. Hence, they had adjusted to the institutional conditions and handled them by aligning with work as their prioritised alternative. This is consistent with their identification as industrial workers rather than students.

\section{Conclusions and Practical Implications}

This study has contributed knowledge about how students handled the academic/vocational divide by recontextualising knowledge between the contexts of school and the workplace in a way that facilitated the formation of a vocational identity as industrial workers. The students handled the academic/vocational divide as knowledgeable actors by changing its meaning, placing more value on practical rather than theoretical knowledge. They also reinforced the separation between the logics and activities connected with school and work. Furthermore, the students saw the importance of having some theoretical knowledge as they recontextualised it as a tool for their future, by selecting knowledge that they perceived as being valuable in industrial workplaces or for proceeding to higher education.

From the findings of this study, I draw two conclusions about how vocational students handle the academic/vocational divide. The first conclusion is an awareness of the low status of vocational education and practical knowledge in dominant discourses on education and knowledge within society. Hence, the students' response is a consequence of the pervading institutionalised rationality of an academic/vocational divide in society. As a result of a deeper analysis, a second conclusion can be drawn that portrays the students as active actors, making conscious choices in order to become employable industrial workers or to proceed with alternative careers in the future.

The students' valuation and prioritisation of practical knowledge and their selection of useful theoretical knowledge is to be understood as an active alignment with the world of work and a rational response to the requirements of the labour market. The students are aware of what kind of knowledge is needed in order to become a skilled and employable industrial worker, and they therefore prioritise and select that knowledge. Hence, they bridge the academic/vocational divide by bringing together practical and theoretical knowledge that is relevant for forming an identity as a skilled industrial worker in the workplace. They are also 
knowledgeable about the requirements and options for gaining eligibility through continuing education, to keep the door open to further education and alternative careers.

A potential limitation of this study could be that the students' experiences are examined in the context of Swedish vocational education, which in many respects differs from vocational educations in other Nordic and European countries, especially considering the large role the school plays in Swedish vocational education (Persson Thunqvist et al., 2019). This study, however, questions the view of vocational students as primarily unmotivated, incapable and uninterested non-academics, which may also be highly relevant to vocational education in other countries. It highlights the insider perspective by showing vocational students to be knowledgeable actors in the process of becoming skilled industrial workers in vocations that require deep and complex knowledge. The students' valuation and selection of different types of knowledge is a strategy chosen by them as knowledgeable actors, actively forming identities aligned with their prospective vocations in industrial work.

\section{References}

Aarkrog, V. (2005). Learning in the workplace and the significance of school-based education: A study of learning in a Danish vocational education and training programme. International Journal of Lifelong Education, 24(2), 137-147. https://doi.org/10.1080/02601370500056268

Andersson, I., Wärvik, G. B., \& Thång, P. O. (2015). Formation of apprenticeships in the Swedish education system: Different stakeholder perspectives. International Journal for Research in Vocational Education and Training, 2(1), 3-4. https://doi.org/10.13152/IJRVET.2.1.1

Armishaw, D. D. (2007). Vocational Identity: It's about Working at Becoming. College Quarterly, 10(2), 1-13. https://collegequarterly.ca/2007-vol10-num02-spring/armishaw.html

Arum, R., \& Shavit, Y. (1995). Secondary vocational education and the transition from school to work. Sociology of Education, 68(3), 187-204. https://hdl.handle.net/1814/16905

Atkins, L., \& Flint, K. J. (2015). Nothing changes: Perceptions of vocational education in England. International Journal of Training Research, 13(1), 35-48. https://doi.org/10.1080/14480220.2015. 1051344

Baartman, L. K., Kilbrink, N., \& de Bruijn, E. (2018). VET students' integration of knowledge engaged with in school-based and workplace-based learning environments in the Netherlands. Journal of Education and Work, 31(2), 204-217. https://doi.org/10.1080/13639080.2018.1433821

Beicht, U., \& Walden, G. (2015). How socially selective is the German system of initial vocational education and training? Transitions into initial vocational training and the influence of social background. Journal of Vocational Education \& Training, 67(2), 235-255. https://doi.org/10.1080/1363 6820.2014 .983955

Berner, B. (2010). Crossing boundaries and maintaining differences between school and industry: Forms of boundary-work in Swedish vocational school. Journal of Education and Work, 23(1), 27-42. https://doi.org/10.1080/13639080903461865 
Billett, S. (2014). The standing of vocational education: Sources of its societal esteem and implications for its enactment. Journal of Vocational Education \& Training, 66(1), 1-21. https://doi.org/10.1080 /13636820.2013.867525

Brockmann, M., \& Laurie, I. (2016). Apprenticeship in England-the continued role of the academicvocational divide in shaping learner identities. Journal of Vocational Education \& Training, 68(2), 229-244. https://doi.org/10.1080/13636820.2016.1143866

Chankseliani, M., James Relly, S., \& Laczik, A. (2016). Overcoming vocational prejudice: How can skills competitions improve the attractiveness of vocational education and training in the UK? British Educational Research Journal, 42(4), 582-599. https://doi.org/10.1002/berj.3218

De Bruijn, E., \& Leeman, Y. (2011). Authentic and self-directed learning in vocational education: Challenges to vocational educators. Teaching and Teacher Education, 27(4), 694-702. https://doi. org/10.1016/j.tate.2010.11.007

Evans, K., Guile, D., Harris, J., \& Allan, H. (2010). Putting knowledge to work: A new approach. Nurse Education Today, 30(3), 245-25. https://doi.org/10.1016/j.nedt.2009.10.014

Evans, K., Guile, D., \& Harris, J. (2011). Rethinking work-based learning: For education professionals and professionals who educate. In M. Malloch, L. Cairns, K. Evans \& B. O’Connor (Eds.), The Sage handbook of workplace learning (pp.149-161). Sage. http://dx.doi.org/10.4135/9781446200940.n11

Ferm, L., Persson Thunqvist, D., Svensson, L., \& Gustavsson, M. (2019). Vocational students' identity formation in relation to vocations in the Swedish industrial sector. Nordic Journal of Vocational Education and Training, 9(2), 91-111. https://doi.org/10.3384/njvet.2242-458X.199291

FitzSimons, G. E., \& Boistrup, L. B. (2017). In the workplace mathematics does not announce itself: Towards overcoming the hiatus between mathematics education and work. Educational Studies in Mathematics, 95(3), 329-349. https://doi.org/10.1007/s10649-017-9752-9

Gustavsson, M., \& Persson Thunqvist, D. (2018). Students' vocational learning: Enabling conditions for putting knowledge to work. In S. McGrath, M. Mulder, J. Papier, \& R. Suart (Eds.), Handbook of vocational education and training: Developments in the changing world of work (pp. 1-18). Springer. https://doi.org/10.1007/978-3-319-94532-3_52

Hyland, T.(2002). On the Upgrading of VocationalStudies: Analysing prejudiceand subordinationinEnglish education. Educational Review, 54(3), 287-296. https://doi.org/10.1080/0013191022000016338

Kilbrink, N., Bjurulf, V., Baartman, L. K., \& de Bruijn, E. (2018). Transfer of learning in Swedish technical vocational education: Student experiences in the energy and industry programmes. Journal of Vocational Education \& Training, 70(3), 455-475. https://doi.org/10.1080/13636820.2018.1437064

Kilbrink, N., Bjurulf, V., Olin-Scheller, C., \& Tengberg, M. (2014). Experiences of educational content in Swedish technical vocational education: Examples from the energy and industry programmes. International Journal of Training Research, 12(2), 122-131. https://doi.org/10.1080/14480220.201 4.11082035

Lavrijsen, J., \& Nicaise, I. (2017). Returns on vocational education over the life cycle: Between immediate labour market preparation and lifelong employability. International Review of Education, 63(2), 257-280. https://doi.org/10.1007/s11159-017-9630-9

Niemi, A. M., \& Rosvall, P. A. (2013). Framing and classifying the theoretical and practical divide: How young men's positions in vocational education are produced and reproduced. Journal of Vocational Education \& Training, 65(4), 445-460. https://doi.org/10.1080/13636820.2013.838287

Nylund, M., Rosvall, P. Å., Eiríksdóttir, E., Holm, A. S., Isopahkala-Bouret, U., Niemi, A. M., \& Ragnarsdóttir, G. (2018). The academic-vocational divide in three Nordic countries: Implications for 
social class and gender. Education Inquiry, 9(1), 97-121. https://doi.org/10.1080/20004508.2018.1 424490

Nylund, M., Rosvall, P. A., \& Ledman, K. (2017). The vocational-academic divide in neoliberal upper secondary curricula: The Swedish case. Journal of Education Policy, 32(6), 788-808. https://doi.org /10.1080/02680939.2017.1318455

Persson Thunqvist, D., \& Axelsson, B. (2011). "Now It's Not School, It's For Real": Negotiated Participation in Media Vocational Training. Mind, Culture and Activity, 19(1), 29-50. https://doi.org/10. 1080/10749039.2011.632048

Persson Thunqvist, D., Hagen Tønder, A., \& Reegård, K. (2019). A tale of two reforms: Institutional change in vocational education and training in Norway and Sweden in the 1990s. European Educational Research Journal, 18(3), 298-313.https://doi.org/10.1177/1474904118823104

Rintala, H., \& Nokelainen, P. (2019). Vocational Education and Learners' Experienced Workplace Curriculum. Vocations and Learning, 13, 1-18. https://doi.org/10.1007/s12186-019-09229-w

Rose, M. (2008). Intelligence, knowledge, and the hand/brain divide. Phi Delta Kappan, 89(9), 632639. https://doi.org/10.1177/003172170808900905

Rosvall, P. Å., Hjelmér, C., \& Lappalainen, S. (2017). Staying in the comfort zones-Low expectations in vocational education and training mathematics teaching in Sweden and Finland. European Educational Research Journal, 16(4), 425-439. https://doi.org/10.1177/1474904116669154

Schaap, H., Baartman, L., \& De Bruijn, E. (2012). Students' learning processes during school-based learning and workplace learning in vocational education: A review. Vocations and Learning, 5(2), 99-117. https://doi.org/10.1007/s12186-011-9069-2

Slaats, A., Lodewijks, H. G., \& van der Sanden, J. M. (1999). Learning styles in secondary vocational education: Disciplinary differences. Learning and Instruction, 9(5), 475-492.

Tønder, A. H., \& Aspøy, T. M. (2017). When work comes first: Young adults in vocational education and training in Norway. International Journal for Research in Vocational Education and Training, 4(3), 270-288. https://doi.org/10.13152/IJRVET.4.3.5

Virolainen, M., \& Persson Thunqvist, D. (2017). Varieties of universalism: Post-1990s developments in the initial school-based model of VET in Finland and Sweden and implications for transitions to the world of work and higher education. Journal of Vocational Education \& Training, 69(1), 47-63. https://doi.org/10.1080/13636820.2016.1238836

Young, M. (1993). Bridging the academic/vocational divide: Two Nordic case studies. European Journal of Education, 28(2), 209-214. https://pascal-francis.inist.fr/vibad/index.php?action=getRecor dDetail\&idt=3996566

\section{Biographical Note}

Lisa Ferm is a PhD-student at the Department of behavioural sciences and learning at Linköping University in Sweden. Her research focus on vocational identity formation amongst students in the upper secondary industrial program. 